\title{
Mental health profile of the elderly community: a cross-sectional study
}

\author{
Perfil de saúde mental de idosos comunitários: um estudo transversal \\ Perfil de salud mental de la comunidad de ancianos: un estudio transversal
}

Renata Cavalcanti Cordeiro' ORCID: 0000-0001-6395-4811

Renata Clemente dos Santos" ORCID: 0000-0003-2916-6832

Gleicy Karine Nascimento de Araújo" ORCID: 0000-0002-4395-6518

Neyce de Matos Nascimento" ORCID: 0000-0001-5557-3365

Rafaella Queiroga Souto" ORCID: 0000-0002-7368-8497

Albanita Gomes da Costa de Ceballos" ORCID: 0000-0002-8658-9981

Fabia Alexandra Pottes Alves" ORCID: 0000-0002-2478-5346

Jeane da Silva Rocha Santos"I ORCID: 0000-0001-5557-6937

'Centro Universitário Facisa. Campina Grande, Paraíba, Brazil. "Universidade Federal da Paraíba. João Pessoa, Paraíba, Brazil. I'I Universidade Federal de Pernambuco. Recife, Pernambuco, Brazil.

How to cite this article: Cordeiro RCC, Santos RC, Araújo GKN, Nascimento NM, Souto RQ, Ceballos AGC, et al. Mental health profile of the elderly community: a cross-sectional study. Rev Bras Enferm. 2020;73(1):e20180191. doi: http://dx.doi.org/10.1590/0034-7167-2018-0191

Corresponding Author: Rafaella Queiroga Souto E-mail: rafaellaqueiroga7@gmail.com

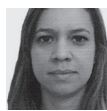

Submission: 04-01-2018

Approval: 09-23-2018

\section{ABSTRACT}

Objective: to describe the mental health profile of the elderly registered in a Family Health Unit in the city of Recife, Pernambuco State. Method: it was a descriptive quantitative study, conducted with 159 elderly through the scales Geriatric Depression, Resilience, Social Support, Life Satisfaction, and Positive and Negative Affects, Mini-Mental State Examination, Stressful Events Inventory and Brazil Old Age Shedule. Results: females, young and literate elderly predominated. Most were satisfied with life, $52.2 \%$ without depressive symptoms, $68.6 \%$ without cognitive impairment, $67.9 \%$ high resilience and $95.8 \%$ high social support, but $62 \%$ of elderly with depressive symptoms showed cognitive deficit. Negative correlation was identified between depression and cognitive impairment, resilience, social support and life satisfaction. Conclusion: assessment of these indicators identifies triggers of psychological distress, assisting the nursing staff in the development of preventive and care actions.

Descriptors: Aged; Nursing; Mental Health; Primary Health Care; Public Health.

\section{RESUMO}

Objetivo: descrever o perfil de saúde mental do idoso cadastrado em uma Unidade de Saúde da Família do município do Recife-PE. Método: tratou-se de um estudo quantitativo descritivo, realizado com 159 idosos mediante as escalas Depressão Geriátrica, Resiliência, Apoio Social, Satisfação com a Vida e Afetos Positivos e Negativos, Mini Exame do Estado Mental, Inventário de Eventos Estressantes e Brazil Old Age Shedule. Resultados: predominou o sexo feminino, idosos jovens e alfabetizados. A maioria apresenta-se satisfeita com a vida, $52,2 \%$ sem sintomas depressivos, $68,6 \%$ sem déficit cognitivo, $67,9 \%$ alta resiliência e $95,8 \%$ alto apoio social, porém $62 \%$ de idosos com sintomas depressivos apresentaram déficit cognitivo. Foi identificada correlação negativa entre a presença de depressão e déficit cognitivo, resiliência, apoio social e satisfação com a vida. Conclusão: a avaliação destes indicadores permite identificar desencadeadores de sofrimento psíquico, auxiliando a equipe de enfermagem no desenvolvimento de ações preventivas e de cuidado.

Descritores: Idosos; Enfermagem; Saúde Mental; Atenção Primária à Saúde; Saúde Pública.

\section{RESUMEN}

Objetivo: describir el perfil de salud mental de los ancianos registrados en una Unidad de Salud Familiar en la ciudad de Recife-PE. Método: fue un estudio cuantitativo descriptivo, realizado con 159 ancianos a través de las escalas Depresión Geriátrica, Resiliencia, Apoyo Social, Stisfacción con la Vida y Efectos Positivos y Negativos, Mini Examen del Estado Mental, Inventario de Eventos Estresantes y Brazil Old Age Shedule. Resultados: predominaron las hembras, jóvenes y alfabetizadas. La mayoría estaban satisfechos con la vida, $52.2 \%$ sin síntomas depresivos, $68.6 \%$ sin deterioro cognitivo, $67.9 \%$ de alta resiliencia y $95.8 \%$ de alto apoyo social, pero $62 \%$ de los ancianos con síntomas depresivos mostraron déficit cognitivo. Se identificó correlación negativa entre depresión y deterioro cognitivo, resiliencia, apoyo social y satisfacción con la vida. Conclusión: la evaluación de estos indicadores permite la identificación de desencadenantes de trastornos psicológicos, ayudando al equipo de enfermería en el desarrollo de acciones preventivas y de atención. Descriptores: Anciano; Enfermeria; Salud Mental; Atención Primaria de Salud; Salud Pública. 
Mental health profile of the elderly community: a cross-sectional study Cordeiro RCC, Santos RC, Araújo GKN, Nascimento NM, Souto RQ, Ceballos AGC, et al.

\section{INTRODUCTION}

Worldwide, population experiences an accelerated aging ${ }^{(1)}$. It is estimated that by 2030 the total number of population will reach $223,126,917$, and $17.98 \%$ represents the number of people aged 60 and over ${ }^{(2)}$, showing a current and future increase in the number of elderly people in Brazil. This setting is presented as a result of decreased fertility rates and increased population's life perspective, which reflects changes in the causes of death profile, which was previously marked by communicable diseases, and Chronic Noncommunicable Diseases prevail today (CNCD $)^{(3)}$.

Among the CNCD are neuropsychological disorders and/or mental disorders, bringing the affected individual a greater degree of disability and impairment in their quality of life $\mathrm{e}^{(4)}$.

Among the main mental disorders, the most common include depression and common mental disorders, characterized by symptoms of anxiety, insomnia, fatigue, irritability, forgetfulness, difficulty concentrating and somatic complaints, presenting negative and limiting impact, considered a serious public health problem ${ }^{(5)}$.

Considering these symptoms, there is a greater chance of psychic impairment as they age ${ }^{(6)}$, considering that CMDs show high prevalence indicators in the Brazilian ${ }^{(6-7)}$ and international setting $^{(8-9)}$.

With advancing age, there is the possibility of some mental and mental impairment appearance, being more common in female elderly $^{(6-7,9)}$, elderly dissatisfied with life, and those with mental disorders ${ }^{(7)}$ or physical ${ }^{(6-7,10)}$, who regularly consumed alcohol and those who mentioned using tobacco at some point in their lives ${ }^{(6)}$.

Disturbances related to alcohol and other licit drugs are also common $^{(3,6)}$. Dementia affects between $1 \%$ and $8 \%$ in the elderly population, constituting an important public health problem and promoting behavioral and psychological changes in this population $^{(3)}$.

A study conducted in the countryside of São Paulo(10) ${ }^{(10}$ shed that the third most frequent cause of seeking elderly people for the Family Health Strategy (FHS) was related to symptoms of mental and behavioral disorders. Of these, 55\% received anxiolytic drug prescriptions and $29.7 \%$ received antidepressants. As Primary Care is considered the gateway to health care, it is worth highlighting the need for greater investment in promoting mental health and preventing mental impairment.

Depression and anxiety are commonly attributed to natural aging, followed by job losses, social losses, changing roles and new health conditions ${ }^{(11)}$. Hence, because they are linked to common everyday facts, there is a failure in diagnosis and proper treatment, as well as a lack of actions aimed at promoting the mental health of the population under discussion.

Mental health, according to the World Health Organization (WHO), is as a condition of well-being in which the individual can be productive, work, cooperate with the community in which he is inserted and to deal with tensions of life ${ }^{(12)}$.

It is important to understand the elderly population mental health situation, considering reflexes in which these pathologies represent for their quality of life and the lack of studies intended for this purpose ${ }^{(6)}$. In addition, there is a need to deepen the phenomenon, seeking actions that envisage symptom prevention and encourage ther independence and autonomy ${ }^{(9,13)}$.

\section{OBJECTIVE}

To describe the mental health profile of the elderly registered in a Family Health Unit in the city of Recife, Pernambuco State.

\section{METHOD}

\section{Ethical aspects}

This project is linked to a research entitled "Impacto de intervenções multidimensionais em idosos cadastrados na atenção primária à saúde e seus cuidadores", approved by the Research Ethics Committee (REC) of Health Sciences Center (HSC) of Universidade Federal de Pernambuco.

\section{Design, place of study and period}

This was a descriptive quantitative cross-sectional study conducted in the city of Recife, Pernambuco, Brazil, from 2016 to 2017.

\section{Population or sample; inclusion and exclusion criteria}

The study included the elderly registered in the area covered by three family health teams of FHU Sítio Wanderley, located in the Microarea III of the Health District IV of Recife.

The sample was calculated by using the finite population formula for epidemiological studies, using a 95\% confidence level and $5 \%$ power of error. Based on this calculation, the resulting sample consisted of 159 elderly.

Sampling was random and systematic. The number of elderly was determined by proportionality among the three teams of the health unit. Every five seniors on each team's list, one was selected and invited to participate in the survey.

The study included people aged 60 years or older, registered in the three family health teams. Those who were terminally excluded were excluded; severe hearing or vision deficits; with severe cognitive impairment. These exclusion criteria were identified by the researcher through observation or information from their guardians.

\section{Study protocol}

Training was carried out for 33 students, 22 from nursing and 11 from occupational therapy, in order to present, discuss and learn to apply the data collection tools that were used in this research, as well as calibrate data collectors.

Interviewers performed data collection in pairs, always accompanied by Community Health Agents ( $\mathrm{CHA}$ ) to ensure the safety of the interviewer and favor the bond with the elderly.

Data collection took place at the residence of the elderly, after clarification of the research objectives, guidance on data confidentiality, availability to participate and signing of the Informed Consent Form. All tools were applied by the interviewer.

For data collection, the following tools were used: Brazil Old Age Shedule (BOAS); Mini-Mental State Examination (MMSE) for cognitive screening; Geriatric Depression Scale (GDS-15) to assess the presence of depressive symptoms; Resilience Scale to assess resilience level; Social Support Scale; Stressful Events Inventory; Life Satisfaction Scale (LSS) and the Positive and Negative Affects Scale. 
Sociodemographic characterization of the studied group was based on the application of the BOAS tool, which is divided into sections that include general information on physical health and utilization of medical and dental services, and mental health ${ }^{(14)}$. From this tool were extracted questions related to age, gender, marital status, literacy, work and income.

MMSE was applied to evaluate the cognitive functions of the elderly. The score of this tool can vary from 0 to 30 points and its cutoff point varies according to the participant's level of education.

To evaluate depressive symptoms, GDS, composed of 15 questions regarding how the person felt in the last week, presenting two answer options that are "yes" or "no" was used. The elderly with a total score equal to or greater than 5 points were classified as depressive symptoms ${ }^{(15)}$.

Social Support Scale was used to identify the degree of social support of the elderly. This tool has 5 answer options from 1 to "never" and 5 to "always". The elderly who scored 0-33 points and high support above 34 points were classified with low support ${ }^{(16)}$.

Stressful Events Inventory consists of 31 items that indicate negative events, such as health problems or marital relationships and parental death, being used to measure the impact of these stressful events on the interviewee's life ${ }^{(17)}$.

LSS consists of 5 questions with answers ranging from 1 (strongly disagree) and 7 (strongly agree). It evaluates how satisfied the respondent is, and the closer to 7 , the more positive the result.

Another tool used was the Positive and Negative Affects Scale. This scale aims to evaluate the frequency of feelings that the interviewee presented in the last days, ranging from 1 (nothing) to 7 (extremely). Results are satisfactory for positive affect items when the response is closer to 7, and for negative affect items the closer to $0^{(18)}$.

\section{Analysis of results, and statistics}

The collected data were entered in double entry by independent digitizers in SPSS version 21.0. Discrepancies were reviewed and corrected by a data collection coordinator. Subsequently, they were analyzed using descriptive statistics (absolute and relative frequency, mean and standard deviation) and inferential statistics (Pearson's Chi-Square Test or Fisher's Exact tTst) when the casels had a number equal to or less than five; and Pearson's Correlation Test). For all analyzes, a significance level of $5 \%(p<0.05)$.

To evaluate strength correlation, the following criteria were used: $r=1$ (perfect); $0.80<r<1$ (very high); $0.60<r<0.80$ (high); $0.40<r<0.60$ (moderate); $0.20<r<0.40$ (low); $0<r<0.20$ (very low); $r=0$ (null), being interpreted in the same way for negative coefficient values.

The use of a parametric test occurred according to the result of the Kolmogorov Smirnov normality test, since the variables presented normal distribution.

\section{RESULTS}

Table 1 shows an association between sociodemographic variables and depressive symptoms, mental state, resilience and social support. It was observed that there was an association ( $p \leq$ 0.05 ) in the variables marital status and housing arrangement with depressive symptoms, and in the variable work with mental state.

In assessing depressive symptoms and social support, predominance occurred in female 70-80-year-old widowed/separated or never married.

Regarding mental state, most participants with cognitive impairment were women, aged 60 to 70 years and widowed/ separated or never married.

Regarding resilience, low resilience was observed in men, over 80 years old, married/living together.

The variables literacy, work, income and housing arrangement did not differ in any of the analyzes, since the elderly who presented the greatest impairment of mental characteristics were the non-literate, who do not work, with income above 3 minimum wages and who live alone.

Table 2 shows that women are more satisfied with life, have more positive and less negative affects than men who participated in this study.

Events that presented the highest prevalence among the 40 stressful events in the stressful events inventory were selected. Among these, the three most prevalent events were: the death of a friend $(n=86 ; 53.8 \%)$, followed by the onset of a disease in the elderly $(n=90 ; 54.6 \%)$ and decreased activities that I liked $(n=89 ; 55.7 \%)$.

In Table 4, there was an association between depressive symptoms, social support and resilience according to mental state. Statistically significant difference was found between mental state and depressive symptoms and resilience.

Table 5 presents the result of the correlation analysis between the total score of GDS, MMSE, resilience, social support and life satisfaction scales. All variables were correlated. The total life satisfaction score showed a moderate and negative correlation with the total GDS score.

Table 1 - Mental characteristics as a function of sociodemographic data of research participants, Recife, Pernambuco, Brazil, 2016-2017

\begin{tabular}{|c|c|c|c|c|c|c|c|c|}
\hline \multirow[b]{2}{*}{ Variables } & \multicolumn{2}{|c|}{ Depressive symptoms } & \multicolumn{2}{|c|}{ Mental state } & \multicolumn{2}{|c|}{ Resilience } & \multicolumn{2}{|c|}{ Social support } \\
\hline & $\begin{array}{c}\text { C } \\
\text { n (\%) }\end{array}$ & $\begin{array}{c}\text { S } \\
\text { n (\%) }\end{array}$ & $\begin{array}{c}\text { C } \\
\text { n (\%) }\end{array}$ & $\begin{array}{c}\text { S } \\
\text { n (\%) }\end{array}$ & $\begin{array}{c}\text { B } \\
\text { n (\%) }\end{array}$ & $\begin{array}{c}A \\
n(\%)\end{array}$ & $\begin{array}{c}\text { B } \\
\text { n (\%) }\end{array}$ & $\begin{array}{c}A \\
n(\%)\end{array}$ \\
\hline \multicolumn{9}{|l|}{ Gender } \\
\hline Male & $15(40.5)$ & $22(59.5)$ & $11(29.7)$ & $26(70.3)$ & $14(37.8)$ & $23(62.2)$ & $1(2.7)$ & $36(97.3)$ \\
\hline Female & $61(50.0)$ & $61(50.0)$ & $39(32.0)$ & $83(68.0)$ & $37(30.3)$ & $85(69.7)$ & $4(3.3)$ & 116(96.7) \\
\hline$p$ value* & \multicolumn{2}{|c|}{0.313} & \multicolumn{2}{|c|}{0.797} & \multicolumn{2}{|c|}{0.391} & \multicolumn{2}{|c|}{$0.849 * *$} \\
\hline \multicolumn{9}{|l|}{ Age } \\
\hline $60-70$ & $58(68.2)$ & $27(31.8)$ & $42(49.4)$ & $43(50.6)$ & $26(30.6)$ & $59(69.4)$ & $2(2.4)$ & 82(97.6) \\
\hline $70-80$ & $34(73.9)$ & $12(26.1)$ & $20(43.5)$ & $2(56.5)$ & $14(30.4)$ & $32(69.6)$ & 2(4.4) & $43(95.6)$ \\
\hline Above 80 & $16(59.3)$ & $11(40.7)$ & $13(48.1)$ & 14(51.9) & $10(37.0)$ & $17(63.0)$ & 1(3.7) & 26(96.3) \\
\hline$p$ value* & \multicolumn{2}{|c|}{0.430} & \multicolumn{2}{|c|}{0.808} & \multicolumn{2}{|c|}{0.803} & \multicolumn{2}{|c|}{$0.807^{* *}$} \\
\hline
\end{tabular}




\begin{tabular}{|c|c|c|c|c|c|c|c|c|}
\hline \multirow[b]{2}{*}{ Variables } & \multicolumn{2}{|c|}{ Depressive symptoms } & \multicolumn{2}{|c|}{ Mental state } & \multicolumn{2}{|c|}{ Resilience } & \multicolumn{2}{|c|}{ Social support } \\
\hline & $\begin{array}{c}\text { C } \\
\text { n (\%) }\end{array}$ & $\begin{array}{c}\text { S } \\
\text { n (\%) }\end{array}$ & $\begin{array}{c}\text { C } \\
\text { n (\%) }\end{array}$ & $\begin{array}{c}\text { S } \\
\text { n (\%) }\end{array}$ & $\begin{array}{c}\text { B } \\
\text { n (\%) }\end{array}$ & $\begin{array}{c}\text { A } \\
\text { n (\%) }\end{array}$ & $\begin{array}{c}\text { B } \\
\text { n (\%) }\end{array}$ & $\begin{array}{c}\text { A } \\
\mathbf{n}(\%)\end{array}$ \\
\hline \multicolumn{9}{|l|}{ Marital status } \\
\hline Accompanied & $8(14.8)$ & $46(85.2)$ & $22(40.7)$ & $32(59.3)$ & $2(3.8)$ & $51(96.2)$ & $14(25.9)$ & $40(74.1)$ \\
\hline Alone & $42(40.0)$ & $63(40.0)$ & $54(51.4)$ & $5(48.6)$ & $3(2.9)$ & $101(97.1)$ & $37(35.2)$ & $68(64.8)$ \\
\hline$p$ value $^{*}$ & \multicolumn{2}{|c|}{0.001} & \multicolumn{2}{|c|}{0.201} & \multicolumn{2}{|c|}{$0.764^{* *}$} & \multicolumn{2}{|c|}{0.234} \\
\hline \multicolumn{9}{|l|}{ Literate } \\
\hline Yes & $30(28.3)$ & $76(71.7)$ & $50(47.2)$ & $56(52.8)$ & $33(31.1)$ & $73(68.9)$ & $4(3.8)$ & $101(96.2)$ \\
\hline No & $20(37.7)$ & $33(62.3)$ & $26(49.1)$ & $27(50.9)$ & $18(34.0)$ & $35(66.0)$ & $1(1.9)$ & $51(98.1)$ \\
\hline$p$ value* & \multicolumn{2}{|c|}{0.227} & \multicolumn{2}{|c|}{0.822} & \multicolumn{2}{|c|}{0.719} & \multicolumn{2}{|c|}{$0.526^{* *}$} \\
\hline \multicolumn{9}{|l|}{ Currently working } \\
\hline Yes & $8(29.6)$ & $19(70.4)$ & $(29.6)$ & $1(70.4)$ & $6(22.2)$ & $21(77.8)$ & $0(0.0)$ & $27(100)$ \\
\hline No & $40(31.7)$ & $86(68.3)$ & $63(50.0)$ & $63(50.0)$ & $42(33.3)$ & $84(66.7)$ & $5(4.0)$ & $146(96.0)$ \\
\hline$p$ value* & \multicolumn{2}{|c|}{0.830} & \multicolumn{2}{|c|}{0.054} & \multicolumn{2}{|c|}{0.259} & \multicolumn{2}{|c|}{$0.289^{* *}$} \\
\hline \multicolumn{9}{|l|}{ Income } \\
\hline$\leq 1 \mathrm{MW}$ & $35(31.0)$ & $78(69.0)$ & $55(48.7)$ & $58(51.3)$ & $39(34.5)$ & $74(65.5)$ & $3(2.7)$ & $109(97.3)$ \\
\hline $1-3 \mathrm{MW}$ & $11(28.9)$ & $27(71.1)$ & $17(44.7)$ & $21(55.3)$ & (23.7) & $29(76.3)$ & $1(2.7)$ & $36(97.3)$ \\
\hline$>3 \mathrm{MW}$ & $4(50.0)$ & $4(50.0)$ & $4(50.0)$ & $4(50.0)$ & $3(37.5)$ & $5(62.5)$ & $1(12.5)$ & $7(87.5)$ \\
\hline$p$ value* $^{*}$ & \multicolumn{2}{|c|}{0.497} & \multicolumn{2}{|c|}{0.908} & \multicolumn{2}{|c|}{0.439} & \multicolumn{2}{|c|}{$0.305^{* *}$} \\
\hline \multicolumn{9}{|c|}{ Housing arrengement } \\
\hline Alone & $12(54.5)$ & $10(45.5)$ & $13(59.1)$ & $9(40.9)$ & $9(40.9)$ & $13(59.1)$ & $2(9.5)$ & $19(90.5)$ \\
\hline $1-4$ & $32(28.6)$ & $80(71.4)$ & $51(45.5)$ & $61(54.5)$ & $35(31.3)$ & $77(68.8)$ & $3(2.7)$ & $108(97.3)$ \\
\hline $5-8$ & $6(24.0)$ & 19(76.0) & 1248.0) & $13(52.0)$ & $7(28.0)$ & 18(72.0) & $0(0.0)$ & $25(100)$ \\
\hline$p$ value* & \multicolumn{2}{|c|}{0.038} & \multicolumn{2}{|c|}{0.508} & \multicolumn{2}{|c|}{0.602} & \multicolumn{2}{|c|}{$0.162^{* *}$} \\
\hline
\end{tabular}

Note: * Pearson's Chi-Square Test; ** Fisher's Exact Test C: with; S: without; B: low; A: high; Alone: widowed, separated or never married; Accompanied: married or living together.

Table 2 - Comparison of life satisfaction and positive and negative affects among genders, Recife, Pernambuco, Brazil, 2016-2017

\begin{tabular}{lcc}
\hline Variables & $\begin{array}{c}\text { Female } \\
\text { M (SD) }\end{array}$ & $\begin{array}{c}\text { Male } \\
\text { M (SD) }\end{array}$ \\
\hline Life satisfaction & $25.82(6.92)$ & $25.08(7.83)$ \\
Positive affects & $22.24(6.51)$ & $22.08(6.84)$ \\
Negative affects & $14.15(6.37)$ & $12.78(5.82)$ \\
\hline
\end{tabular}

Note: M: mean; SD: Standard Deviation.

Table 3 - Frequency of stressful events among survey participants, Recife, Pernambuco, Brazil, 2016-2017

\begin{tabular}{lcc}
\hline Stressful events & $\mathbf{n}$ & $\%$ \\
\hline Death of a friend & 102 & 64.2 \\
Death of a close relative & 86 & 53.8 \\
Wife got sick & 64 & 35.4 \\
The elderly himself became ill & 90 & 54.6 \\
Take care of sick wife & 44 & 22.3 \\
Loss of purchasing power & 57 & 35.4 \\
Decreased activities you enjoyed & 89 & 55.7 \\
\hline
\end{tabular}

Table 4 - Mental state assessment according to the presence of depressive symptoms, social support and resilience level, Recife, Pernambuco, Brazil, 2016-2017

\begin{tabular}{lccc}
\hline & \multicolumn{2}{c}{ Mental state } & \\
Variables & $\begin{array}{c}\text { Without cognitive } \\
\text { deficit } \\
\mathbf{n}(\%)\end{array}$ & $\begin{array}{c}\text { With cognitive } \\
\text { deficit } \\
\mathbf{n}(\%)\end{array}$ & $\begin{array}{c}\boldsymbol{p} \\
\text { value* }\end{array}$ \\
\hline $\begin{array}{c}\text { Depressive symptoms } \\
\text { With symptoms }\end{array}$ & $45(41.3)$ & $31(62.0)$ & 0.015 \\
Without symptoms & $64(58.7)$ & $19(38.0)$ & \\
$\begin{array}{l}\text { Social support } \\
\text { Ow support }\end{array}$ & $3(2.8)$ & $2(4.1)$ & 0.666 \\
High support & $105(97.2)$ & $47(95.9)$ & \\
\hline
\end{tabular}

\begin{tabular}{lccc}
\hline Variables & $\begin{array}{c}\text { Mental state } \\
\text { Without cognitive } \\
\text { deficit } \\
\mathbf{n}(\%)\end{array}$ & $\begin{array}{c}\text { With cognitive } \\
\text { deficit } \\
\mathbf{n}(\%)\end{array}$ & $\begin{array}{c}\boldsymbol{p} \\
\text { value* }\end{array}$ \\
\hline $\begin{array}{l}\text { Resilience } \\
\text { Low resilience } \\
\text { High resilience }\end{array}$ & $29(26.6)$ & $22(44.0)$ & 0.029 \\
\hline Note:*Pearson's Chi-Square Test & $80(73.4)$ & $28(56.0)$ & \\
\hline
\end{tabular}

Table 5 - Correlation between total Geriatric Depression Scale score and total Mini-Mental State Examination score of resilience, social support and Life Satisfaction Scale scale. Recife, Pernambuco, Brazil, 2016-2017

\begin{tabular}{lcc}
\hline Variables & \multicolumn{2}{c}{ GDS total score } \\
& $\begin{array}{l}\text { Correlation } \\
\text { coefficient }\end{array}$ & $\boldsymbol{p}$ value* \\
\hline MMSE total score & -0.266 & 0.001 \\
Total Resilience Scale score & -0.326 & 0.000 \\
Total Social Support Scale score & -0.225 & 0.005 \\
LSS total score & -0.519 & 0.000 \\
\hline
\end{tabular}

Note: *Pearson's Correlation Test; GDS: Geriatric Depression Scale; MMSE: Mini-Mental State Examination; LSS: Life Satisfaction Scale.

\section{DISCUSSION}

Concerning the socio-demographic and economic data, this study highlights the predominance of females, widows, divorced or single who are literate and have as their main source of income a minimum wage value retirement. This economic condition supports families of 2 to 4 people. These data corroborate other studies, which point out the female predominance in elderlyrelated research, a fact strongly influenced by the greater female longevity and its expressiveness in health services ${ }^{(6,19-22)}$.

Regarding income, $71.1 \%$ of the elderly is only paid a minimum wage. However, its influence on family income is a relevant fact, 
as its role as financial responsible and family provider is evident, which can lead to emotional overload and consequent mental illness ${ }^{(23-24)}$.

The elderly who still develop some work activity were predisposed to the appearance of some impairment of their mental state. However, idleness in the elderly can generate negative feelings such as anger, anguish, frustration and sadness ${ }^{(25)}$. These feelings may be unfavorable to maintaining the mental health of the elderly. In this sense, despite susceptible conditions related to working capacity of the elderly, systematic review performed in one study did not corroborate the findings of this research, as it indicates that work, even though associated with body damage and difficulty in performing functions, it acts as an important protective factor against depression, disability and frailty, maintaining well-being, good cognitive level and independence in daily activities ${ }^{(26-27)}$.

It is worth noting that the increase in longevity has led to significant changes in the age profile of workers, as well as its design, and therefore the way the work activity is organized is responsible for a healthy or unhealthy aging ${ }^{(28)}$. Thus, one of the factors that may contribute to women becoming more prone to develop mental disorders is the overload of activities, evidenced by their insertion in the labor market and maintenance of functions related to the family role ${ }^{(20)}$.

This overload leads to anguish, frustration and sadness, feelings that may be unfavorable to maintaining the mental health of the elderly. The idle period of individuals in the old age stage is directly proportional to the worsening of negative affects. There is a need to provide this population with daily activities that can occupy their minds and make sense of their existence ${ }^{(25)}$.

In this study, although positive affects overlap with negative ones, the presence of depressive symptoms was higher in the elderly who had lower life satisfaction rates $(r=-0.519 ; p=0.000)$. Regarding the evaluation of affects and life satisfaction, women presented higher averages ${ }^{(29)}$ for positive affects and life satisfaction, differing from the results found in a study conducted in the city of Campina Grande, Paraíba State. This data allows the realization that female longevity is not interfering with their life satisfaction.

This result coincides with that found in a study conducted in Rio Grande do Sul, where $52.1 \%(n=87)$ of the elderly have depressive symptoms and are dissatisfied with life ${ }^{(20)}$.

This assessment of life satisfaction can be considered subjective and may be related to quality of life. Thus, it would be expected that elderly people with mental disorders report life dissatisfaction due to the damage that these disorders can cause to the individual ${ }^{(7)}$.

Concerning the data related to life satisfaction, results were consistent with the household survey study, conducted through a quantitative, cross-sectional and analytical approach, developed with elderly residents in an urban area of Uberaba (MG), Brazil(30). This study points out the relationship between self-esteem and quality of life, in which the higher the self-esteem, the higher the quality of life, the latter being an impact factor for users' feeling of joy, satisfaction and happiness, protecting them from psychic illness.

However, although the sample did not present high indicators of depressive symptoms, there was an association between them and the elderly without any type of marital relationship and living alone. This data corroborates the results found in a study in Southeastern Brazil(19).

Regarding family arrangement, the study conducted with the elderly in Paraná State ${ }^{(31)}$ points out that the change in family structure, characterized by an increase in widowed or divorced elderly living alone, associated with the challenges of postmodern society, may justify the greater prevalence to trigger depressive symptoms.

Social support and the quality of relationships surrounding the elderly can positively influence the variables optimism and stress, developing resilience and, consequently, the ability to overcome difficult situations through the help of quality family and social experience, reducing stress ${ }^{(32)}$.

According to the results pointed out by this study, the most prevalent stressors are all related to losses, be it the death of a friend, autonomy due to the emergence of some disease in the elderly and third the reduction of activities that they liked.

Therefore, it is worth noting that aging is permeated by accumulations of symbolic and real losses, given that at this stage of life there is a significant decrease in physical vigor and feeling of productivity. Losses of loved ones are frequent, resulting in weakened emotional relationships and diminished social life, as widowhood overwhelms old age with the weight of loneliness and the sense of loss of the source of social support ${ }^{(33)}$.

Significant association between cognitive impairment and depressive symptoms was observed. Aging changes may influence cognitive decline and contribute to the emergence of physical, psychological and social manifestations. This cognitive decline can be assessed as a risk factor for the onset of depressive symptoms and dementia ${ }^{(34)}$.

Thus, increased depression in the elderly is a factor directly proportional to mental state problems, as well as inversely proportional to resilience, social support, and life satisfaction levels. Corroborating this finding, research conducted by Ribeiro et al (2018) in Bahia State with elderly residents in the urban area shows that depressive symptoms have a great impact on the individual's living conditions, reflecting chaotic conditions on the elderly population health. Oftenly the elderly, due to the forgetfulness of their relatives, are on the fringes of society, without emotional and psychological support, which makes it difficult to establish affective, family and social relationships that are so important for human beings to live in society ${ }^{(33)}$.

Although depression is among the diseases that most affect the mental health of the elderly, the results of the present study showed that the higher the total score of depressive symptoms, the lower the total MMSE score, thus the greater the cognitive deficit. Although depression is a disabling mental disorder responsible for the loss of autonomy, functionality and aggravation of other disorders, and directly affects the quality of life, it is still underdiagnosed because health professionals believe that their symptoms are typical of aging ${ }^{(27,35)}$.

However, this study shows, with a small margin of difference, that most elderly did not present depressive symptoms (52.2\%). This can be justified due to the results that indicate that $68.6 \%$ of the elderly do not have cognitive deficit and high resilience, characteristics that contribute significantly to the increase of 
the quality of life of individuals and act as a factor of emotional protection $^{(36)}$.

A descriptive study conducted with elderly patients from the Geriatrics Outpatient Clinic / HC-UNICAMP points out that resilience is an emotional protection factor in elderly people suffering from chronic diseases, as it is associated with the preservation of the individuals' functionality, as well as a lower predisposition to depressive symptoms ${ }^{(36)}$.

In the sample, depressive symptoms were negatively correlated with resilience level. Thus, the elderly who exhibit these symptoms are those who have low resilience. This data corroborates the results found in the study conducted in São Paulo, in which $54.16 \%(n=13)$ of the elderly with depressive symptoms had low resilience ${ }^{(37)}$.

Furthermore, an effective strategy used by health professionals in primary care for mental health care of the elderly has been soft care technologies, through humanized reception and building bonds. Integrative and complementary practices of SUS (Sistema Único de Saúde - Brazilian Unified Health System) were also used, as in the case of integrative community therapy, it has been shown to be an effective care tool for protection and prevention of psychological distress for contributing as a support network and facilitator to build affective bonds that reflects the feeling of belonging to a group, increasing the self-esteem and the sense of well-being of individuals ${ }^{(37-38)}$.

\section{Study limitations}

The cross-sectional design limits the implications of the present study as it does not allow an assessment of causality or longitudinality. In addition, the present study did not diagnose individuals' mental characteristics, as it used only screening scales that indicate changes that need to be further investigated.

\section{Contributions to Nursing, Health or Public Policy}

The results of this study contribute to the improvement of nursing care, as it makes evident the need for mental health care of the elderly in primary and community care, in order to identify triggers of psychological distress and lead to common mental disorders, a factor that favors the progression to cases of mental illness, being depression as its greatest exponent. Nevertheless, it is imperative that care during aging is carried out comprehensively and attentive to life realities, as well as permeated by soft care technologies aimed at the elderly in the community.

\section{CONCLUSION}

The profile found in the studied sample was of elderly people who did not show mental health decline, who often experience positive affects and are satisfied with life. A statistically significant association was identified between cognitive deficit and depressive symptoms and social support; and moderate negative correlation of life satisfaction with depressive symptoms.

Although not a longitudinal study, the measurement of these indicators broadens the scientific literature on the subject, provides scientific evidence for further studies with other types of design and enables nursing professionals to be able to list factors that trigger psychological distress and impairment of mental health in the elderly. Moreover, it gives them subsidies for the development of actions to promote mental health and improvements to the general health situation.

\section{REFERENCES}

1. Organização Mundial da Saúde (OMS). Relatório Mundial de Envelhecimento e Saúde [Internet]. Brasília: OMS; 2015 [cited 2018 Mar 11]. Available from: https://sbgg.org.br/wp-content/uploads/2015/10/OMS-ENVELHECIMENTO-2015-port.pdf

2. Instituto Brasileiro de Geografia e Estatistica (IBGE). Projeção da População do Brasil e unidades da federação por sexo e idade para o período de 2000 a 2030 [Internet]. Rio de Janeiro: IBGE; 2015 [cited 2018 Mar 11]. Available from: http://www.ibge.gov.br/apps/populacao/projecao/

3. Malta DC, Silva MMAD, Moura LD, Moraes Neto OL. The implantation of the Surveillance System for Non-communicable Diseases in Brazil, 2003 to 2015: successes and challenges. Rev Bras Epidemiol. 2017;20(4): 661-75. doi: 10.1590/1980-5497201700040009

4. Lichtman JH, Froelicher ES, Blumenthal JA, Carney RM, Doering LV, Frasure-Smith N, et al. Depression as a risk factor for poor prognosis among patients with acute coronary syndrome: systematic review and recommendations: a scientific statement from the American Heart Association. Circulation. 2014;129(12):1350-69. doi: 10.1161/CIR.0000000000000019

5. Yimam K, Kebede Y, Azale T. Prevalence of common mental disorders and associated factors among adults in Kombolcha Town, northeast Ethiopia. J Depress Anxiety. 2014;(Suppl 1):1-6. doi: 10.4172/2167-1044.S1-007

6. Silva PAS, Rocha SV, Santos LB, Santos CA, Amorim CR, Vilela ABA. Prevalência de transtornos mentais comuns e fatores associados entre idosos de um município do Brasil. Ciênc Saúde Colet. 2018;23(2):639-46. doi: 10.1590/1413-81232018232.12852016

7. Martins AMEBL, Nascimento JE, Souza JGS, Sá MAB, Feres SBL, Soares BP, et al. The association between common mental disorders and subjective health conditions among the elderly. Ciênc Saúde Colet. 2018;21(11):3387-98. doi: 10.1590/1413-812320152111.07842015

8. Andreas S, Schulz H, Volkert J, Dehoust M, Sehner S, Suling A, et al. Prevalence of disorders in elderly people: The European Mentdis_ICF65+ study. Br J Psychiatry. 2017;210(2):125-31. doi: 10.1192/bjp.bp.115.18046

9. Noorbala AA, Faghihzadeh S, Kamali K, Yazdi SAB, Hajebi A, Mousavi MT, et al. Mental Health Survey of the Iranian adult population in 2015. Arch Iran Med. 2017;20(3):128-34. doi: 0172003/AIM.003

10. Onofri Júnior VA, Martins VS, Marin MJS. Elderly health care in the Family Health Strategy and the prevalence of common mental disorders. 
Mental health profile of the elderly community: a cross-sectional study Cordeiro RCC, Santos RC, Araújo GKN, Nascimento NM, Souto RQ, Ceballos AGC, et al.

Rev Bras Geriatr Gerontol. 2016;19(1):21-33. doi: 10.1590/1809-9823.2016.15004

11. Possatto JM, Rabelo DF. Condições de saúde psicológica, capacidade funcional e suporte social de idosos. Rev Kairós. 2017;20(2):45-58. doi: 10.23925/2176-901X.2017v20i2p45-58

12. World Health Organization (WHO). Mental Health: a state of well-being [Internet]. Geneva: WHO; 2014 [cited 2018 Mar 11$]$. Available from: https://www.who.int/features/factfiles/mental_health/en/

13. Araújo GKN, Sousa RCR, Souto RQ, Silva Júnior EG, Eulálio MC, Alves FAP, et al. Functional capacity and depression in elderly. J Nurs UFPE On Line. 2017;11(10):3778-86. doi: 10.5205/1981-8963-v11i10a22627p3778-3786-2017

14. Porciúncula RDCR, Carvalho EF, Barreto KML, Leite VMM. Perfil socioepidemiológico e autonomia de longevos em Recife-PE, Nordeste do Brasil. Rev Bras Geriatr Gerontol. 2014;17(2):315-25. doi: 10.1590/S1809-98232014000200009

15. Guerin JM, Copersino ML, Schretlen DJ. Clinical utility of the 15-item geriatric depression scale (GDS-15) for use with young and middleaged adults. J Affect Disord. 2018;241:59-62. doi: 10.1016/j.jad.2018.07.038

16. Martins RML. A relevância do apoio social na velhice. Rev Mill [Internet]. 2016 [cited 2018 Set 10];31(10):128-34. Available from: https:// revistas.rcaap.pt/millenium/article/view/8422

17. Mazo GZ, Balbé GP, Medeiros PA, Namam M, Ferreira EG, Benedetti TRB. Nível de resiliência em idosas praticantes e não praticantes de exercício físico. Motricidade. 2016;12(4):4-14. doi: 10.6063/motricidade.6138

18. Galinha IC, Pereira CR, Esteves F. Versão reduzida da escala portuguesa de afeto positivo e negativo-PANAS-VRP: Análise fatorial confirmatória e invariância temporal. Psicologia [Internet]. 2014 [cited 2018 Sept 10];28(1):50-62. Available from: http://www.scielo.mec.pt/ scielo.php?script=sci_abstract\&pid=S0874-20492014000100005\&lng=es\&nrm=.pf

19. Oliveira SC, Santos AA, Pavarini SCI. The relationship between depressive symptoms and family functioning in institutionalized elderly. Rev Esc Enferm USP. 2014;48(1):65-71. doi: 10.1590/S0080-623420140000100008

20. Bretanha AF, Facchini LA, Nunes BP, Munhoz TN, Tomasi E, Thumé E. Depressive symptoms in elderly living in areas covered by Primary Health Care Units in urban area of Bagé, RS. Rev Bras Epidemiol. 2015;18(1):1-12. doi: 10.1590/1980-5497201500010001

21. Ribeiro PCPSV, Marque RMD, Ribeiro MP. Geriatric care: ways and means of providing comfort. Rev Bras Enferm [Internet]. $2017 ; 70(4): 830-7$. [Thematic Edition "Good Practices: Fundamentals of care in Gerontological Nursing"]. doi: 10.1590/0034-7167-2016-0636

22. Lenardt MH, Sousa JAV, Grden CRB, Betiolli SE, Carneiro NHK, Ribeiro DKMN. Gait speed and cognitive score in elderly users of the primary care service. Rev Bras Enferm. 2015;68(6):851-6. doi: 10.1590/0034-7167.2015680623i

23. Saidel MGB, Campos CJG. Family of older adults with mental disorder: perception of mental health professionals. Rev Bras Enferm [Internet]. 2017;70(4):753-60. [Thematic Edition "Good Practices: Fundamentals of care in Gerontological Nursing"]. doi: $10.1590 / 0034-7167-2016-064624$

24. Paiva MM, Tavares DMS. Physical and psychological violence against the elderly: prevalence and associated factors. Rev Bras Enferm. 2015;68(6):727-33. doi: 10.1590/0034-7167.2015680606i

25. Oliveira JM, Rozendo CA. Instituição de longa permanência para idosos: um lugar de cuidado para quem não tem opção? Rev Bras Enferm. 2014;67(5):773-9. doi: 10.1590/0034-7167.2014670515

26. Amorim JSC, Salla S, Trelha CS. Factors associated with work ability in the elderly: systematic review. Rev Bras Epidemiol. 2014;17(6):830-41. doi: 10.1590/1809-4503201400040003

27. Ribeiro MS, Borges MS, Araújo TCCF, Souza MCS. Coping strategies used by the elderly regarding aging and death: an integrative review. Rev Bras Geriatr Gerontol. 2017;20(6):869-77. doi: 10.1590/1981-22562017020.170083

28. Rodrigues MR, Bretas ACP. O envelhecimento no trabalho na perspectiva de trabalhadores da área de enfermagem. Trab Educ Saúde. 2015;13(2):343-60. doi: 10.1590/1981-7746-sip00034

29. Nunes RP, Melo RLP, Silva Júnior EG, Eulálio MC. Relationship between coping and subjective well-being of elderly from the interior of the Brazilian northeast. Psicol Reflex Crit. 2016;29:1-8. doi: 10.1186/s41155-016-0032-x

30. Tavares DMS, Matias TGC, Ferreira PCS, Pegorari MS, Nascimento JS, Paiva MM. Quality of life and self-esteem among the elderly in the community. Ciênc Saúde Colet. 2016;21(11):3557-64. doi: 10.1590/1413-812320152111.03032016

31. Lentsck MH, Pilger C, Schoereder EP, Prezotto KH, Mathias TAF. Prevalence of depressive symptoms and signs of dementia in the elderly in the community. Rev Eletr Enf. 2015; 17(3):1-8. doi: 10.5216/ree.v17i3.34261

32. Oliveira NA, Souza EN, Luchesi BM, Inouye K, Pavarini SCI. Stress and optimism of elderlies who are caregivers for elderlies and live with children. Rev Bras Enferm [Internet]. 2017;70(4):697-703. [Thematic Edition “Good Practices: Fundamentals of care in Gerontological Nursing"] doi: 10.1590/0034-7167-2017-008833

33. Ribeiro VS, Rosa RS, Sanches GJC, Ribeiro IJS, Casotti CA. Qualidade de vida e depressão em domicílios no contexto doméstico. Enferm Actual. 2018;34:53-66. doi: 10.15517/revenf.v0i34.30983

34. Nunes WA, Dias FA, Nascimento JS, Gomes NC, Tavares DMS. Cognição, funcionalidade e indicativo de depressão entre idosos. Rev Rene. 2018;17(1):103-11. doi: 10.15253/2175-6783.2016000100014

35. Santos MA. Câncer e suicídio em idosos: determinantes psicossociais do risco, psicopatologia e oportunidades para prevenção. Ciênc Saúde Colet. 2017;22(9):3061-75. doi: 10.1590/1413-81232017229.05882016 
36. Fontes AP, Fattori A, D’Elboux MJ, Guariento ME. Resiliência psicológica: fator de proteção para idosos no contexto ambulatorial. Rev Bras Geriatr Gerontol. 2015;18(1):7-17. doi: 10.1590/1809-9823.2015.13201

37. Moura SG, Ferreira Filha MO, Moreira MASP, Simpson CA, Tura LFR, Silva AO. Social representations of integrative community therapy by the elderly. Rev Gaúcha Enferm. 2017; 38(2): e55067. doi: 10.1590/1983- 1447.2017.02.55067

38. Penha AAG, Barreto JAPS, Santos RL, Rocha RPB, Morais HCC, Viana MCA. Tecnologias na promoção da saúde de idosos com doenças crônicas na Atenção Primária à Saúde. Rev Enferm UFSM. 2015;5(3):406-14. doi: 10.5902/2179769217160 